\title{
Other voices, other rooms? The relevance of dubbing in the reception of audiovisual products
}

\author{
Víctor M. González Ruiz \& Laura Cruz García \\ Universidad de Las Palmas de Gran Canaria
}

Unlike subtitling, the process of dubbing does not give the audience the opportunity to fully perceive the cultural gap between what they hear and see, and their own reality. This takes on a new dimension when the customs and the characters which are being depicted in the foreign film are not the 'standard' ones (i.e. those from the US) but those belonging to 'marginal' cultures (e.g. European, African or Asian).

Let us take the imaginary example of a Moroccan film in which a character representing an Arabic-speaking Tuareg, whose voice has been dubbed into Spanish, uses the same kind of perfect Castilian as audiences usually hear in the mouth of a New York police officer in an American series dubbed into Spanish. The cultural impact of a different language is supposedly lost when the dubbing makes all the voices sound the same.

This paper will discuss the influence of dubbing on the audience's perception of a range of films in the context of Spain's film industry. We will offer an empirical study with the aim of identifying the elements which filmgoers use to situate a film, and even question whether (and to what extent) the process of dubbing effaces the cultural and national origin of a film. The conclusions drawn will contribute to the research on the reception of (audiovisual) translation.

\section{Introduction: the reception of dubbed and subtitled films}

Dubbing is usually regarded as a domesticating process by means of which the source text's 'foreignness' is concealed from the audience by making the characters in the film speak the viewers' own language. Likewise, it is alleged that the filmgoers who see a subtitled film can more easily identify the elements on screen which do not belong to their culture.

According to this presupposition, which is widely accepted (Danan 1991; Hart 1994; Mera 1999), dubbing obstructs the recognition of 'the other' and prevents the audience, at least partially, from becoming aware of the distinct idiosyncrasies of the people and the places depicted in the screenplay. In principle, this would be true for all films which are commercially released. However, we believe that a difference might be made, at least, between high profile US major productions, which, according to figures, occupy a very large portion of Spain's theatrical venues, and the small percentage of non-US feature films which make their way to the Spanish cinemas only with great difficulty ${ }^{1}$. 
In spite of the protectionist measures taken by Spain and other European countries in order to preserve their national industries (Agost 1997: 47 ), it is a fact that Hollywood-related distribution companies operating in Spain hardly leave any room for the release of works which have been produced outside the US or which have not been backed by US major producers (e.g. Reviriego 2007). In the context of today's world film industry, this means either that 'marginal' (as defined below) motion pictures are shown only in a very limited way, or, in an increasing manner, that their authors make an effort to imitate US production values (budget, art direction, cast profile, plot, soundtrack) in order to get a wider release.

This state of the industry concerning non-US films raises some questions as to whether filmgoers are aware of the national origin of the small number of non-US releases, what leads the audience to identify the nationality of a film in any case, and whether the dubbing of motion pictures from Europe, Africa or Asia for the Spanish market affects the way in which filmgoers receive these works. For example, in multiplexes where almost all the films on offer are dubbed mainstream American productions, we wonder to what extent the audience choosing a dubbed German film will be able to hear the 'other voices' and to enter the 'other rooms' of a story coming from a non-US culture.

According to our initial hypothesis, dubbing might have an effect on the reception of films, and this effect could vary depending on the industrial profile of the production translated.

\section{Back to the roots: the difficulties of ascertaining the origin of a film}

As stated by Mazrui (1999), globalisation goes hand in hand with homogenisation and hegemonisation. This assertion seems particularly true for the audiovisual industry landscape nowadays. In international seminars, film schools and festival workshops, producers, directors and screenwriters from around the world are taught how to make and market their films in order to be successful; this normally implies the copying of the production strategies traditionally employed by Hollywood studios, as well as the detailed examination of the creative and promotional keys to recent successes ${ }^{2}$.

Besides, as far as the commercial showing of films is concerned, the traditional premiere of new works in theatres is starting to be replaced by more global release strategies and showcases (e.g. Internet downloads), which demonstrate the tendency of the industry's major 'players' to arrange the release of their products considering the global market as a whole. Even traditionally restricted areas like China, one of the most significant potential markets for films, are no longer a closed territory for international releases, and non-Chinese producers are managing to reach this country's screens with the help of a variety of commercial strategies (e.g. by making 'national' films in partnership with local companies [Frater 2007]). 
Such a globalised film industry mirrors today's worldwide financial circumstances, where multinational transactions and alliances focus on global strategies and profits, and "revenues are shared by numerous producers" (Gambier \& Suomela-Salmi 1994: 244). As a result, economic and artistic cooperation between different countries has brought about a new situation in the way in which motion pictures are made and sold internationally. For example, four of the top-ten films by admissions in Europe in 2004 were coproduced by at least three countries: Troy (2004, Wolfgang Petersen, USA/UK/Malta), Lord of the Rings: The Return of the King (2003, Peter Jackson, USA/New Zealand/Germany), The Last Samurai (2003, Edward Zwick, USA/New Zealand/Japan) and Bridget Jones: The Edge of Reason (2004, Beeban Kidron, UK/USA/France/Ireland/Spain/Germany) (European Audiovisual Observatory, 2007a).

All these new conditions contribute to the existence of a film industry 'terra nullius', an intricate network of multinational financers and artists which, mostly following patterns of (usually American) past successful filmmaking, produce motion pictures designed to become international hits. Under these circumstances, ascertaining the national origin of any film developed in such a way is sometimes an impossible task.

\subsection{What is a 'marginal film'?}

Notwithstanding this Babel-like setting, national film industries around the world still produce their own genuinely domestic works. Featuring home actors and technicians, and usually partly financed with the help of Government funds, these frequently low-budget films are normally given a limited release on their own national screens; and some of them, relying on their artistic merits, are shown in international film festivals, from where they may be exported to other countries ${ }^{3}$.

In Europe, with some exceptions, these national productions do not perform well at the box office, whether in their own countries or abroad. In 2006, for instance, film admissions in the 25 member States of the European Union were broken down according to the origin of the films as follows: 64\% US; 5.7\% US-Europe; 27.6\% Europe; and 2.7\% rest of the world (European Audiovisual Observatory 2007b). Likewise, in Spain, $71.22 \%$ of the domestic film market in 2006 belonged to US motion pictures, as opposed to the meagre $15.43 \%$ corresponding to Spanish productions, or the $11.81 \%$ of films from other European countries (Ministerio de Cultura 2007a).

Behind these figures, the following may be listed as likely factors: (a) the predominance of US distribution companies almost everywhere in the world; (b) the expertise of US companies' marketing divisions, which have succeeded in attracting global attention towards a Hollywood-related star system where little place is left for national talent; and (c) the inability of 
small industries, like Spain's, to publicise their own products (García Fernández 2003). Furthermore, unlike US films and most of the coproductions previously described, which are shot in English, these national motion pictures use the native tongue of the particular country where they have been made. As the statistics seem to prove, this might be a disadvantage today: between 2002 and 2006, only nine non-English speaking motion pictures made it to the yearly list of the 70 most-seen films worlwide (Box Office Mojo 2007).

Since these national films often tell stories set in the most immediate surroundings of the domestic writer and the director, which is something which audiences accustomed to American smash hits are not very keen on ${ }^{5}$, and because they are usually defeated in the struggle for a share of the market, we call these works 'marginal films' or films coming from a 'marginal culture'. 'Marginal' is used here from the perspective of popular appeal, as we consider that, based on the figures, Belgian or Spanish filmgoers seem to feel more at home with the comings and goings of a Philadelphian baseball team, than with the affairs of a group of thirtysomethings in Athens or Hamburg.

The poor returns of these 'marginal' films in Spain, where they most frequently go through the dubbing process to be released, cast doubt on whether there is any connection between the commercial run of a 'marginal' film and the fact that the actors in it speak the same language (i.e. dubbed Spanish) as the audience. On the surface, the figures described above suggest that dubbing might not be a critical factor when it comes to commercial success.

\subsection{Imitating US production values}

Producers from 'marginal' film industries around the world have tried to transcend the barriers of the art house circuit by imitating US film production values and, increasingly, by borrowing English as their shooting language. Partly answering some of the questions in this paper, national filmmakers seem to believe that audiences will feel more attracted towards works which resemble Hollywood-style motion pictures or, in Orias's words (2005: 286), which "follow the 'rules' of the Hollywood model". Thus, they copy stories, characters and the art direction of well-known hits, bring in actors of world fame and increase their budgets, often taking advantage of multinational cooperation, in order to match the box-office performance of American productions.

French director Luc Besson's The Fifth Element (1997, France) and The Messenger: The Story of Joan of Arc (1999, France), Spanish Alejandro Amenábar's The Others (2001, France/Spain/USA) and German Tom Tykwer's Perfume: The Story of a Murderer (2006, Germany/France/Spain), are clear-cut examples of mostly European motion pictures which have purposefully been stripped of any national idiosyncrasy in order to better appeal to average audiences (and which originate from the 
industry's 'terra nullius' already mentioned). Likewise, there are other national films of a lower profile which also mirror the successful trends of US production; these are mainly genre works which, even though closely following the patterns of American thriller or horror films, still feature identifiable elements from their country of origin (e.g. Dutch-speaking Amsterdamned $d^{6}$ and German-speaking Anatomie $)$.

Considering that these motion pictures, by means of marketing strategies and the way in which their stories are told, openly attempt to look like potentially successful US films, the concealment of their original language through dubbing in countries like Spain might be the ultimate factor in their quest for commercial success. In such a context, the decisive question is to what extent audiences are likely to mistake the origin of a film when this is being served to them as a standard (fake) American dish and there is no trace of the language used in the source version.

\section{An empirical study on the reception of dubbed and subtitled films}

With the intention of answering the questions which have been posed in previous pages, we carried out an empirical study focusing on the differences in the reception of dubbed and subtitled films. This study is based on a questionnaire, a procedure which, according to Toury (1991), constitutes an appropriate means to assess the acceptability of translations in the target culture and which, together with cloze tests, is a useful and efficient method for product-oriented empirical studies. The results of this survey, even though approximate, will surely add new elements of discussion to the growing interest in field research within Translation Studies.

\subsection{Procedure and implementation}

The main purpose in our research was to distinguish the elements which filmgoers rely on when determining the national origin of a motion picture which they have just seen, and to observe whether there is any variation in the answers given for dubbed and subtitled works. The conclusions drawn should partially clarify the alleged culture-neutralizing effect of dubbing in films of varying production properties.

The experimental procedure involved the following steps: (a) five films from different production backgrounds were selected; (b) a questionnaire was designed in order to extract information on the perceived origin of the motion pictures; (c) in a controlled setting, ten groups of six filmgoers, chosen at random, watched the subtitled or dubbed version of one of these films on a small screen via DVD, and subsequently filled in the questionnaires ${ }^{8}$; and (d) the answers obtained were analysed concentrating on the purpose already mentioned.

Supplemented by questions regarding personal details (i.e. age, educational background, occupation) and the subject's habits as a filmgoer, the 
central items in the questionnaire were the following: (a) Which country do you think the film was made in?; (b) Why do you believe that this is the country of origin of the film? Give at least four reasons why you think so; and (c) Has the film's dubbing/subtitling influenced your opinion of the film? A sample of the questionnaire is included here as an appendix.

Since we are particularly interested in putting the study of dubbing in the context of today's world film industry, the five motion pictures selected ranged from prototypical US productions to low-budget European works. Thus, they have been classified according to industrial factors:

- $\quad$ Mainstream American films: Presumed Innocent (1990, Alan J. Pakula, USA). This is a film developed by Warner Bros. Pictures, one of the Hollywood 'majors', which was widely released in all markets around the world. As usual in this type of productions, marketing strategies focus on the attraction power of its star cast (in this case, Harrison Ford).

- European films d'auteur: Pauline à la plage (1983, Eric Rohmer, France), and Il bagno turco (1997, Ferzan Ozpetec, Italy/Turkey/Spain). These are 'marginal' films in the sense previously described; that is to say, European art house productions with a relatively limited release outside their countries of origin, and where the director is seen as the ultimate creator of the film.

- $\quad$ 'Hybrid' films: September (1987, Woody Allen, USA), and Anatomie (2000, Stefan Ruzowitzky, Germany). These are works which seem out of place within their own national production structures. On the one hand, September is an independent American film by a director who is regarded as an auteur, as seen from a European perspective; and whose creations, despite the frequent presence of some Hollywood stars in the cast, are not big commercial successes. On the other hand, Germany's Anatomie is a European film which manifestly combines the traditional elements of an American suspense motion picture with those of Hollywood's terror films designed for young audiences. After success in its national market, it was exported to other foreign countries and a sequel (Anatomie 2, 2003, Stefan Ruzowitzky, Germany) followed.

The sixty people who took part in the experiment were aged between 20 and 50. They did not share a common professional or educational background, and their individual habits as filmgoers were quite different. Our intention was to avail ourselves of the views of a group as heterogeneous as possible, so that these could be representative of the average filmgoer's perception. Given the variety of participants, the question of whether any of the subjects had previously seen any of the films selected was beyond our control; for this reason, we chose motion pictures whose theatrical admission figures had fallen short of constituting a success (except in the case of Presumed Innocent $)^{9}$. Moreover, whether the participants had seen the films 
or not, there was the ever-present risk that they could recognise the circumstances of any film because of their exposure to the media at the times when the feature films were publicised and released.

As part of the controlled situation in which the subjects participated in this research, they did not know which film they were going to watch until they started to see it. Furthermore, they could not comment on any aspect of the film until they had completed the questionnaire. With these restrictions, we wanted to make sure that no one could influence anyone else's views and, consequently, their answers.

\subsection{The results}

In order to better fulfill our research objectives, we classified the results from the questionnaires taking into consideration the industrial profile of the films selected. Thus, we compared, on the one hand, Anatomie and Presumed Innocent; and, on the other hand, September and the European films d'auteur (Pauline à la plage and Il bagno turco). In the former pair of motion pictures, both works intend to woo (at least outside the US) the same potential audience, and they approximately share Hollywood-style production values. In the latter, September reproduces, in an American context, production and artistic elements which are typical of European art house films, whose fans are the most likely to pay to see the Woody Allen work.

Table 1 shows, in decreasing order of frequency, the factors which, according to the subjects who saw the subtitled versions of Anatomie and Presumed Innocent, were determinant in ascertaining the national origin of each of these productions.

Table 1: Anatomie vs. Presumed Innocent. Most frequently mentioned factors used to determine country of origin for the subtitled version

\begin{tabular}{|c|c|c|c|}
\hline \multicolumn{2}{|c|}{ Anatomie } & \multicolumn{2}{|c|}{ Presumed Innocent } \\
\hline Factors & Frequency & Factors & Frequency \\
\hline Places mentioned & 5 & Actors & 5 \\
\hline Cultural references & 4 & Cultural references & 4 \\
\hline Language & 4 & Accent & 3 \\
\hline Setting & 3 & Story & 3 \\
\hline Atmosphere & 2 & Car models & 2 \\
\hline Credits & 2 & Setting & 2 \\
\hline Written messages & 1 & Language & 2 \\
\hline Characters' names & 1 & Architecture & 2 \\
\hline
\end{tabular}

Even though all the subjects correctly thought that Anatomie was German and that Presumed Innocent was American, some differences may be noted between the factors which each group of viewers alleged as decisive to arrive at their conclusions about the subtitled works' national origin. Linguistic elements, such as the credits, written messages on screen and the names 
of the characters, were exclusively pointed out with regard to Anatomie; likewise, the 'language' factor was perceived as relatively more relevant in the German film. On the contrary, those who watched Presumed Innocent directed most of their attention to non-verbal factors, such as the recognition of the actors, the plot and American lifestyle elements (e.g. car models and architecture).

In Table 2, the data refer to the subjects' impressions after seeing the dubbed renderings of Anatomie and Presumed Innocent.

Table 2: Anatomie vs. Presumed Innocent. Most frequently mentioned factors used to determine country of origin for the dubbed version

\begin{tabular}{|l|c|l|c|}
\hline \multicolumn{2}{|c|}{ Anatomie } & \multicolumn{2}{c|}{ Presumed Innocent } \\
\hline Factors & Frequency & \multicolumn{1}{c|}{ Factors } & Frequency \\
\hline Places mentioned & 4 & Cultural references & 4 \\
\hline Actors & 3 & Setting & 4 \\
\hline Characters' names & 2 & Actors & 2 \\
\hline Physical appearance & 2 & Written messages & 1 \\
\hline Credits & 2 & Characters' names & 1 \\
\hline 'Style' of the film & 2 & Decoration & 1 \\
\hline Atmosphere & 1 & Car models & 1 \\
\hline Clothes & 1 & & \\
\hline
\end{tabular}

Again, visual and lifestyle factors seem to be the most relevant for the viewers of the dubbed version of Presumed Innocent when guessing at its nationality. Being a mainstream American production, the actors and the type of story dealt with were familiar to the viewers and provided enough signs to identify it as a US film. For Anatomie, since the characters now spoke perfect Spanish, the places mentioned as part of the story (e.g. Heidelberg) helped the subjects, more than anything else, to determine its German origin.

Significantly, one of the subjects who saw the dubbed version mistook the country of production of Anatomie and thought that it was the USA. This viewer referred to aspects such as the story, the setting, the style and the actors in the film, in order to justify his answer. Since the information which the original language could provide was no longer available due to the dubbing process, the Hollywood-style production values of the German feature film apparently confused the subject's perception of the motion picture.

With regard to the second set of productions to be compared, September in contrast to Pauline à la plage and Il bagno turco, Tables 3 and 4 show the results for the subtitled versions.

Table 3: September vs. Il bagno turco. Most frequently mentioned factors used to determine country of origin for the subtitled version 


\begin{tabular}{|l|c|l|l|}
\hline \multicolumn{2}{|c|}{ September } & \multicolumn{2}{c|}{ Il bagno turco } \\
\hline \multicolumn{1}{|c|}{ Factors } & Frequency & \multicolumn{1}{c|}{ Factors } & Frequency \\
\hline Cultural references & 6 & Language & 6 \\
\hline Places mentioned & 5 & Credits & 3 \\
\hline Actors & 4 & Characters' names & 2 \\
\hline Director & 4 & Setting & 2 \\
\hline Language & 2 & Story & 2 \\
\hline Decoration & 2 & Places mentioned & 1 \\
\hline Music & 2 & Atmosphere & 1 \\
\hline Credits & 2 & Music & 1 \\
\hline
\end{tabular}

Table 4: September vs. Pauline à la plage. Most frequently mentioned factors used to determine country of origin for the subtitled version

\begin{tabular}{|l|c|l|l|}
\hline \multicolumn{2}{|c|}{ September } & \multicolumn{2}{c|}{ Pauline à la plage } \\
\hline \multicolumn{1}{|c|}{ Factors } & Frequency & \multicolumn{1}{c|}{ Factors } & Frequency \\
\hline Cultural references & 6 & Language & 7 \\
\hline Places mentioned & 5 & Setting & 5 \\
\hline Actors & 4 & Characters' names & 2 \\
\hline Director & 4 & Car plates & 2 \\
\hline Language & 2 & Places mentioned & 2 \\
\hline Decoration & 2 & Car models & 2 \\
\hline Music & 2 & Story & 1 \\
\hline Credits & 2 & Physical appearance & 1 \\
\hline
\end{tabular}

Not surprisingly, language is the key factor when it comes to identifying the nationality of a subtitled European art house film. French, Italian and Turkish languages are here the most noticeable signs of the 'marginal' cultures which Pauline à la plage and Il bagno turco belong to. The viewers also found the places where the stories take place (e.g. the French coast; Rome and Istambul) revealing as far as the country of production of the works is concerned. With respect to September, the linguistic element was scarcely mentioned, and the subjects mostly paid attention to the presence in the credits of an iconic director and well-known actors, the cultural references in the film and the geographical names (e.g. New York) involved in the action.

The fact that one of the viewers of the subtitled version of September mistook it for a British film is also worthy of remark. In order to justify her decision, this subject pointed out elements such as clothes, decoration and some cultural references she related to British culture (e.g. the teapot, the constant rain and the way the characters behaved towards each other). Together with the subject's probable lack of awareness of the differences in accent between American and British English, the film's intimate atmosphere and its telling of a sad and profound story (elements frequently linked to European productions) might have misled this viewer. 
Finally, Tables 5 and 6 include the most frequent answers given by the participants who saw the dubbed versions of September, Pauline à la plage and Il bagno turco.

Table 5: September vs. Il bagno turco. Most frequently mentioned factors used to determine country of origin for the dubbed version

\begin{tabular}{|l|c|l|c|}
\hline \multicolumn{2}{|c|}{ September } & \multicolumn{2}{c|}{ Il bagno turco } \\
\hline \multicolumn{1}{|c|}{ Factors } & Frequency & \multicolumn{1}{c|}{ Factors } & Frequency \\
\hline Places mentioned & 3 & Cultural references & 5 \\
\hline Actors & 3 & Language & 4 \\
\hline Story & 3 & Setting & 3 \\
\hline Decoration & 2 & Physical appearance & 3 \\
\hline 'Style' of the film & 2 & Places mentioned & 2 \\
\hline Atmosphere & 1 & Credits & 2 \\
\hline Clothes & 1 & Architecture & 1 \\
\hline Director & 1 & Atmosphere & 1 \\
\hline
\end{tabular}

Table 6: September v. Pauline à la plage. Most frequently mentioned factors used to determine country of origin for the dubbed version

\begin{tabular}{|l|c|l|c|}
\hline \multicolumn{2}{|c|}{ September } & \multicolumn{2}{c|}{ Pauline à la plage } \\
\hline \multicolumn{1}{|c|}{ Factors } & Frequency & \multicolumn{1}{c|}{ Factors } & Frequency \\
\hline Places mentioned & 3 & Setting & 5 \\
\hline Actors & 3 & Style & 3 \\
\hline Story & 3 & Places mentioned & 3 \\
\hline Decoration & 2 & Physical appearance & 3 \\
\hline 'Style' of the film & 2 & Characters' names & 3 \\
\hline Atmosphere & 1 & Car models & 2 \\
\hline Clothes & 1 & Atmosphere & 2 \\
\hline Director & 1 & Story & 2 \\
\hline
\end{tabular}

The viewers of the dubbed versions of the European films relied, above all, on the places where the film is set, and on those which are mentioned by the characters as part of the plot (e.g. Paris). Deprived of the original voices of the films, the subjects also observed other 'external' aspects to decide on the origin of the production; among these, the physical appearance and names of the characters. In the case of Il bagno turco, the cultural references of an apparently distant Islamic country like Turkey were the most significant factor for the viewers' response. In contrast, September shows a diverse range of factors, where the places referred to in the story and the identification of the actors are again among the most frequently mentioned ones.

Besides, as with its subtitled version, a participant watching the dubbed variant of September also believed that the film was British, arguing that, since the plot took place inside a house from beginning to end, the 
style was typically European. In this case, where there was no possible confusion between accents of English (it was dubbed into Spanish), it seems likely that the viewer felt disoriented by the production values of the motion picture, which, instead of being the usual ones for a US commercial film, somehow followed the 'stylesheet' of art house European works.

As a final remark, Pauline à la plage, in its dubbed rendering, was considered an Italian production by one of the subjects. Another thought it was a French-Italian co-production. However, in spite of the incorrect answers, both of them agreed on the fact that it was a European film.

\section{Conclusions}

According to the results obtained, audiences seem to find the main source of information about a film's origin in its production values (i.e. Hollywood stars v. little-known European actors; blockbusters v. low-budgeted works; easy-to-swallow plots v. intimate and profound stories). All the subjects, with the exceptions noted, were successful at ascertaining the country of production of the film which they had seen, both in the subtitled and dubbed versions. Thus, art house European works and mainstream American films are apparently regarded respectively by viewers as having very precise characteristics as commercial products. In the cases of Presumed Innocent, Pauline à la plage and Il bagno turco, whether the film was dubbed or subtitled did not make any difference to the subjects' correct impression of their nationality.

However, when a film does not correspond exactly to the production cliché of its country of origin (i.e. a 'hybrid' motion picture, as it has been defined here), the expectations of the traditional filmgoer may be at odds with the actual elements which they are seeing on screen. As a result, it seems that they are more likely to mistake the origin of a picture, as happened with the 'hybrid' examples employed in our research. One of the participants mistook the dubbed version of Anatomie for an American motion picture. And another thought that the Spanish-speaking rendering of September corresponded to a British production. In both instances, we believe that, together with the misleading production style, the concealment of the original language through dubbing should be regarded as significant when explaining the viewers' errors.

After implementing our experiment, it could be asserted that our initial hypothesis (i.e. dubbing might have an effect on the reception of films, and this effect could vary depending on the industrial profile of the production translated) is true to a certain degree. Further, some additional informal research suggests that, when subjects are shown only selected extracts from dubbed 'hybrid' films, more participants mistake the nationality of the film ${ }^{10}$.

Apropos of this overall result, it should not go unnoticed that Benno Fürmann, the German actor who plays one of the main characters in 
Anatomie, and Alessandro Gassman, the Italian star of Il bagno turco, speak Spanish with the voice of Luis Posada, who happens to be the dubbing actor for Hollywood personalities such as Jim Carrey, Johnny Depp and Leonardo DiCaprio. Or that Camilo García, the dubbing actor who most frequently lends his Spanish voice to American star Harrison Ford (e.g. in Presumed Innocent), is also the usual voice in Spain of European actors such as Philippe Noiret (e.g. in Nuovo cinema Paradiso, 1988, Giuseppe Tornatore, Italy/France) and Gérard Depardieu (e.g. in Novecento, 1976, Bernardo Bertolucci, Italy/France/West Germany/USA) (El Doblaje 2007).

As some scholars have pointed out (e.g. Zaro 2000), there is no final evidence of the influence that dubbing and subtitling may have on the reception or the commercial success of audiovisual products. Our results, together with future work based on this study, should add some reliable elements of discussion to the research in this field of Translation Studies.

\section{Bibliography}

Agost, Rosa (1997). Traducción y doblaje: palabras, voces e imágenes. Barcelona: Ariel.

Box Office Mojo (2007). Yearly Box Office Worldwide. http://www.boxofficemojo.com. (last visited on 3 January 2007).

Danan, Martine (1991). "Dubbing as an Expression of Nationalism". Meta XXXVI (4), 606-614.

El Doblaje (2007). Base de datos del doblaje en España. http://www.eldoblaje.com. (last visited on 26 January 2007).

Europa Press (2007). Más de la mitad de los españoles afirma que las películas nacionales son 'mediocres' y 'para minorías', según un estudio (Madrid, 12 de junio). http://www.europapress.es. (last visited on 15 June 2007).

European Audiovisual Observatory (2007a). Press release (Strasbourg, 4 May 2005): Major markets buoyant in 2004 as European Union cinema admissions top 1 billion milestone. http://www.obs.coe.int (last visited on 15 February 2007).

European Audiovisual Observatory (2007b). Press release (Strasbourg, 10 May 2007): European cinema bounces back in 2006. http://www.obs.coe.int. (last visited on 15 June 2007).

Frater, Patrick (2007). "Disney takes local route in China". Variety, June 28. http://www.variety.com (last visited on 4 July 2007).

Gambier, Yves \& Suomela-Salmi, Eija (1994). "Subtitling: A Type of Transfer”. Eguíluz, Federico et al. (eds.) Trasvases culturales: literatura, cine y traducción. Vitoria: Universidad del País Vasco, 243-252.

García Fernández, Emilio Carlos (2003). "La fragilidad comunicativa del cine español”. Axencia Audiovisual Galega (coord.) Oficina de produción: Ferramentas de produción: Guía de profesionais. http://www.axenciaaudiovisualgalega.org/public/ (last visited on 30 July 2007).

Hart, Margaret (1994). “Subtítulos o doblaje: ¿cuál cumple mejor con el trasvase cultural?”. Eguiluz, Federico et al. (eds.) Trasvases culturales: literatura, cine y traducción. Vitoria: Universidad del País Vasco, 261-268.

Hollywood Reporter (2007). Marketing, tech talk highlight Shanghai panel. $\mathrm{http} / / / \mathrm{www}$. hollywoodreporter.com/hr/content_display/international/news (last visited on on 5 July 2007).

Mazrui, Ali (1999). "Globalisation and Cross-Cultural Values: The Politics of Identity and Judgement”. Arab Studies Quarterly, 21 (3), 97-108.

Mera, Miguel (1999). "Read my Lips: Re-evaluating Subtitling and Dubbing in Europe". Links \& Letters, 6, 73-85.

Ministerio de Cultura (2007a). Cuota de mercado de películas de la Unión Europea y Estados Unidos. http://www.mcu.es/cine (last visited on 1 February 2007).

Ministerio de Cultura (2007b). Base de datos de películas calificadas. http://www.mcu.es/cine (last visited on 1 July 2007). 
Nielsen et al. (2007). Venezia Digitale. http://www.venezia-digitale.com/ (last visited on 16 July 2007).

Orias, Beatriz (2005). "The Globalizing Influence of Hollywood: The Case of Scotland as seen through Rob Roy (1995)". Oliete, Elena et al. (ed.) Culture and Power. Culture and Society in the Age of Globalisation, 10. Universidad de Zaragoza, 285-294.

Reviriego, Carlos (2007). "Distribución. Debate. Miedos y certezas en el mercado". Cahiers du cinéma. España, 2, 51-54.

SGAE (Sociedad General de Autores de España) et al. (2007). European films crossing borders. http://www.eufilmscrossingborders.com (last visited on 15 July 2007).

Toury, Gideon (1991). "Experimentation in Translation Studies: Achievements, Prospects and Some Pitfalls". Tirkkonnen-Condit (ed.) Empirical Research in Translation and Intercultural Studies. Tübingen: Gunter Narr, 45-66.

Zaro, Juan Jesús (2000). "Perspectiva social del doblaje y la subtitulación”. Lorenzo, Lourdes et al. (eds.) Traducción subordinada (I). El doblaje. Vigo: Universidade de Vigo, 127-138.

\section{Filmography}

Amsterdamned (1988)

Netherlands

Dir. Dick Maas

Anatomie (2000)

Germany

Dir. Stefan Ruzowitzky

Anatomie 2 (2003)

Germany

Dir. Stefan Ruzowitzky

Apocalypto (2006)

USA

Dir. Mel Gibson

Astérix \& Obélix: Mission Cléopâtre (2002)

France

Dir. Alain Chabat

Bridget Jones: The Edge of Reason (2004)

UK/USA/France/Ireland/Spain/Germany

Dir. Beeban Kidron

Der Untergang (2004)

Germany

Dir. Oliver Hirschbiegel

Gegen die Wand (2004)

Germany

Dir. Fatih Akin

Good bye, Lenin (2003)

Germany

Dir. Wolfgang Becker

Hero/Ying xiong (2002)

China/Hong Kong

Dir. Zhang Yimou

House of Flying Daggers/Shi mian mai fu (2004)
China/Hong Kong

Dir. Zhang Yimou

Il bagno turco (1997)

Italy/Turkey/Spain)

Dir. Ferzan Ozpetec

Kung Fu Hustle/Kung fu (2004)

China/Hong Kong

Dir. Stephen Chow

Lord of the Rings: The Return of the King (2003)

USA/New Zealand/Germany

Dir. Peter Jackson

Novecento (1976)

Italy/France/West Germany/USA)

Dir. Bernardo Bertolucci

Nuovo cinema Paradiso (1988)

Italy/France

Dir. Giuseppe Tornatore

Pauline à la plage (1983)

France

Dir. Eric Rohmer

Perfume: The Story of a Murderer (2006)

Germany/France/Spain

Dir. Tom Tykwer

Presumed Innocent (1990)

USA

Dir. Alan J. Pakula

September (1987)

USA

Dir. Woody Allen 


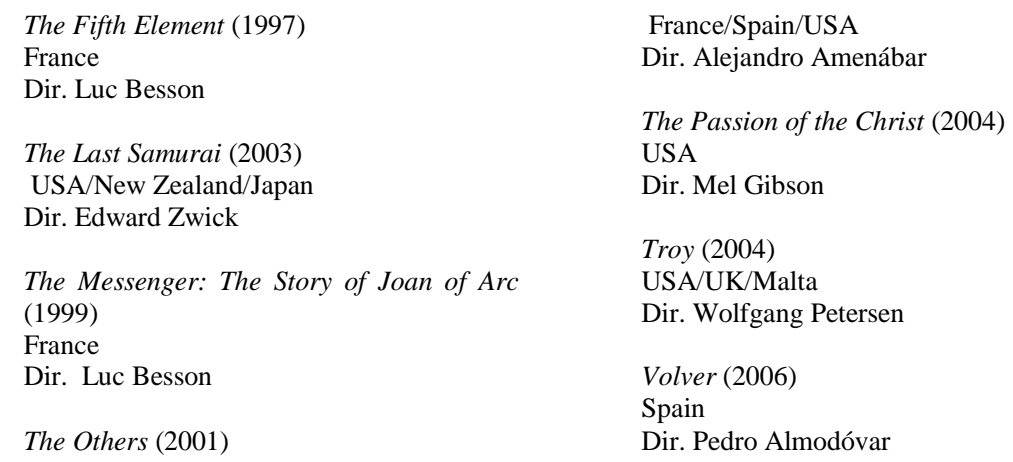

\section{Appendix: Questionnaire sample}

The following is a sample of the questionnaire employed. For some of the items, subjects were given a limited set of alternative answers (see square brackets).

Ahora que has visto la película, por favor, responde a las siguientes preguntas:

1. ¿Qué edad tienes?

2. ¿Cuál es tu nivel de formación? [Ninguno; educación primaria; educación secundaria; universidad]

3. ¿Cuál es tu profesión?

4. Además del español, ¿de qué idiomas tienes conocimiento?

5. ¿Cuál crees que es el país de origen de la película que acabas de ver?

6. ¿Qué cosas de la película te han llevado a pensar que ese es el país de origen? Indica al menos cuatro cosas.

7. ¿Cómo describirías la calidad del doblaje de la película que acabas de ver? [Excelente; buena; regular; mala; muy mala]

¿Quieres añadir algún comentario?

8. ¿El doblaje ha influido en tu opinión sobre la película? [Sí; no; no lo sé] ¿Quieres hacer algún comentario?

9. ¿Cuántas películas ves cada semana aproximadamente? 
10. ¿Dónde ves esas películas? Indica el número de películas que ves en cada uno de los siguientes formatos: [TV; DVD; salas comerciales de cine; cineclubes y filmotecas; otras salas; descargas de Internet]

11. ¿Cómo sueles ver las películas? [Dobladas; en versión original subtitulada; de ambas formas, en la misma proporción]

1 Even though this paper will focus on Spain, we believe that some of the claims in it may be applied to other European countries of dubbing tradition.

2 For example, Berlin, Cannes and San Sebastián film festivals feature the annual seminar "European films crossing borders", which, with the motto "achieving success in marketplaces!", is supported by the EU MEDIA Training Programme (SGAE et al., 2007). Likewise, workshops on how to handle the new technological landscape for global media products abound in all kinds of film events [e.g. "Venezia Digitale" (Nielsen et al., 2007) and Shanghai's "Increasing film market value: Revolution of marketing and distribution" (Hollywood Reporter, 2007), both held in 2007].

3 For example, Gegen die Wand (2004, Fatih Akin, Germany), found a place in markets outside Germany after winning the Golden Bear at the International Berlin Film Festival in February 2004. Likewise, the films by South Korean author Kim Ki-Duk have been regularly released in European theatres only after their award-winning presence in major continental festivals from around 2000.

4 These films are Hero/Ying xiong (2002, Zhang Yimou, China/Hong Kong); Astérix \& Obélix: Mission Cléopâtre (2002, Alain Chabat, France); Good bye, Lenin (2003, Wolfgang Becker, Germany); Der Untergang (2004, Oliver Hirschbiegel, Germany); House of Flying Daggers/Shi mian mai fu (2004, Zhang Yimou, China/Hong Kong); Kung Fu Hustle/Kung fu (2004, Stephen Chow, China/Hong Kong); Volver (2006, Pedro Almodóvar, Spain); and, in a league of their own, The Passion of the Christ (2004, Mel Gibson, USA) and Apocalypto (2006, Mel Gibson, USA).

5 In Spain, a survey released by the Universidad Complutense de Madrid's Instituto de Pensamiento Estratégico in June 2007 showed that $58.7 \%$ of the 1,500 Spanish people approached think that Spanish films are "mediocre or totally uninteresting", while $43.5 \%$ of the subjects said that they dislike their national motion pictures because of the themes and topics which they deal with (Europa Press, 2007).

6 Amsterdamned (1988, Dick Maas, Netherlands).

7 Anatomie (2000, Stefan Ruzowitzky, Germany).

8 Each film was watched by twelve people: six of them saw it in its original version with subtitles in Spanish; and the other six saw the film dubbed into Spanish. This made a total of sixty subjects.

9 As an essential feature of the type of motion picture which it represents, Presumed Innocent was a box-office success, with 1,236,608 admissions in Spain. In contrast, the other four films performed poorly in Spanish cinemas: Pauline à la plage (94,295 admissions), Il bagno turco (189,528), September (221,008), and Anatomie (116,210) (Ministerio de Cultura, 2007b).

${ }^{10}$ In this classroom experience, a group of Spanish university students were shown a rather misleading short sequence of a 'hybrid' film without any easily identifiable cultural elements. 